\title{
The Principle of Good Neighbourliness and the European Neighbourhood Policy
}

\author{
Prof. Dr. Roman Petrov*
}

Updated version of this paper is forthcoming in: D. Kochenov and E. Basheska (eds.), Good Neighbourly Relations in the European Legal Context (Brill Nijhoff, 2015)

\section{Introduction}

Unprecedented geopolitical and security changes that culminated in deep political crisis in Ukraine in 2014 have brought new challenges to the EU's external policy towards the East. It appeared that the European Neighbourhood Policy (ENP) and the Eastern Partnership (EaP) failed to prevent escalating civil conflict in Ukraine and withdrawal of some of the EU eastern neighbours from the course of European integration. The ENP was born in 2004 with ambitious objective to avoid the emergence of new dividing lines between the enlarged EU and the EU's neighbourhood and to strengthen the prosperity, stability and security beyond the EU borders in line with the principle of good neighbourliness. However these objectives look too far to be fully achieved today. In the meantime the EU's neighbourhood is an area of active and hidden civil conflicts, intricate border disputes and escalating security threats. Does it mean that the principle of good neighbourliness failed to play its role?

The first part of the chapter is devoted to study of the scope and content of the ENP and the $\mathrm{EaP}$ and role of the principle of good neighbourliness within these policies. The second part of the chapter analyses the impact of the principle of good neighbourliness on the 'post-Crimea' and 'post-Donbass' EU neighbourhood.

\section{European Neighbourhood Policy and the principle of good neighbourliness}

The first draft of the ENP was outlined in the European Commission's Communication 'On Wider Europe' in March 2003, followed by a Strategy Paper on the ENP in May 2004. ${ }^{1}$ Hitherto, the European Commission made three proposals (in December 2006, in May 2011 and in May 2012) as to how the ENP could be further strengthened and improved. ${ }^{2}$ Today, the ENP framework formally embraces 16 EU's closest geographical and 'political' neighbours - Algeria,

\footnotetext{
*Jean Monnet Chair in EU Law and Head of Jean Monnet Centre of Excellence at the National University of KyivMohyla Academy, Ukraine.

${ }^{1}$ Communication from the Commission to the Council and the European Parliament 'Wider Europe Neighbourhood: A New Framework for Relations with our Eastern and Southern Neighbours' (COM(2003) 104 final). For detailed academic overview of the ENP see Steven Blockmans and Adam Lazowski, (eds.) The European Union and its neighbours (The Hague, T.M.C. Asser Press 2006). Also See Communication from the European Commission 'Paving the way for a New Neighbourhood Instrument' (COM(2003) 393 final), Communication from the European Commission 'European Neighbourhood Policy Strategy Paper' COM(2004) 373 final.

${ }^{2}$ Communication from the Commission to the Council and the European Parliament 'On Strenghening the European Neighbourhood Policy' (COM(2006) 726 final). Joint Communication the European Parliament, the Council, the European Economic and Social Committee and the Committee of Regions 'A New Response to a Changing Neighbourhood' (COM(2011) 303). Joint Communication the European Parliament, the Council, the European Economic and Social Committee and the Committee of Regions 'Delivering on a new Neighbourhood Policy' (JOIN(2012) 14final).
} 
Armenia, Azerbaijan, Belarus, Egypt, Georgia, Israel, Jordan, Lebanon, Libya, Moldova, Morocco, Occupied Palestinian Territory, Syria, Tunisia and Ukraine.

Gradually the ENP was further enriched and supplemented with regional and multilateral co-operation initiatives: the Eastern Partnership (launched in May 2009), the Union for the Mediterranean (the Euro-Mediterranean Partnership, formerly known as the Barcelona Process, re-launched in Paris in July 2008), the Black Sea Synergy (launched in February 2008), and the Partnership for Democracy and Shared Prosperity with the Southern Mediterranean (launched in March 2011).

The ENP embodies the philosophy of the EU external action towards its neighbourhood that is to create "“a ring of friends" surrounding the Union and its closes European neighbours, from Marocco to Russia and the Black Sea' 'sharing everything with the Union not institutions'. In a nutshell the ENP offered the neighbouring countries so called 'privileged relationship' with the EU that is based on a mutual commitment to European common values (democracy and human rights, rule of law, good governance, market economy principles and sustainable development). ${ }^{4}$ Ultimate objectives of the ENP are: political association and deeper economic integration; increased mobility and more people-to-people contacts; access to the EU Internal Market. However, the achievement of the above objectives depends on the extent to which the European common values are effectively shared by the neighbouring countries. The European Commission plays a role of ultimate arbiter of a level of efficiency of sharing the European common values by the neighbouring countries by means of issuing yearly country reports. Structure and content of these country reports resemble documents produced in time of preaccession of the countries of the Central and Eastern Europe.

The ENP's core objective is to set up a 'privileged relationship' ${ }^{5}$ of the EU with it geographical and political neighbours buil[t] on mutual commitment to common values principally within the fields of the rule of law, good governance, the respect for human rights, including minority rights, the promotion of good neighbourly relations (emphasis added)'. ENP founding documents refer to the principle of good neighbourliness in context of need of the settlement of conflicts between the EU neighbouring countries which contributes to better security on the EU's borders thereby recognising the principle of good neighbourliness as a part of the European common values to be shared by all the EU neighbouring countries. ${ }^{7}$ However the ENP does not extend the scope of application of the principle of good neighbourliness beyond the EU neighbourhood thereby creating a sort of a dividing line between the EU's neighbouring countries and other third countries which are not embraced by the ENP. In other words the ENP targets the promotion of good neighbourly relations only within the EU's

\footnotetext{
${ }^{3}$ Speech by Romano Prodi 'A Wider Europe - A Proximity Policy as the key to stability' at the Sixth ECSA-World Conference 'Peace, Security And Stability International Dialogue and the Role of the EU', Brussels, 5-6 December 2002, available at < http://europa.eu/rapid/press-release_SPEECH-02-619_en.htm>, accessed 20.09.2014.

${ }^{4}$ After adoption of the Treaty of Lisbon the European common values are enshrined in Article 2 TEU: 'The Union is founded on the values of respect for human dignity, freedom, democracy, equality, the rule of law and respect for human rights, including the rights of persons belonging to minorities. These values are common to the Member States in a society in which pluralism, non-discrimination, tolerance, justice, solidarity and equality between women and men prevail'.

${ }^{5}$ As provided in Communication from the European Commission 'European Neighbourhood Policy Strategy Paper' $\operatorname{COM}(2004) 373$ final at 3.

${ }^{6} \mathrm{Ibid}$, at 3 .

${ }^{7}$ For example, the ENP documents equate the promotion of the settlement of the conflicts and the need to develop good neighbourly relations between the EU's neighbouring countries (Communication from the European Commission ‘European Neighbourhood Policy Strategy Paper' COM(2004) 373 final at 11).
} 
neighbouring countries and the EU. Therefore it is unfortunate that the ENP did not envisage any sort of engagement into effective implementation of the principle of good neighbourliness of key regional and global security players like the Russian Federation.

The ENP complements but not substitutes existing bilateral agreements between the EU and the neighbouring countries. In the meantime, the ENP countries are parties either to Partnership and Cooperation Agreements (PCA) (some of them will became parties to Association Agreements with the EU) or to EuroMediterranean Association Agreements (EMAA). ${ }^{8}$ Common institutions established under the framework of these agreements monitor the implementation of the ENP while the European Commission conducts annual ENP Progress Reports.

2.1 Place of the principle of good neighbourliness within the core principles of the European Neighbourhood Policy

The ENP is an EU External Policy based on three core principles: differentiation, conditionality and joint ownership and common values. These principles are being applied in the course of bilateral relations between the EU and every neighbouring country. The principles of differentiation, conditionality and joint ownership ensure that any further progress in relations between the EU and its neighbouring countries can be developed and more privileged and advanced relations can be build up conditional to progress of the neighbouring countries within the ENP's action areas. ${ }^{9}$ Unfortunately the ENP documents do not regard the principle of good neighbourliness as a core principle of the ENP along the principles of differentiation, conditionality and joint ownership. Nevertheless the principle of good neighbourliness underpins the objective of the settlement of conflicts between the EU neighbouring countries and constitutes the foundation of the European common values and must be shared by the parties to the ENP. Furthermore it can be argued that the principle of good neighbourliness complements the core principles of the ENP.

\section{a) Principle of differentiation}

The principle of differentiation is based on an assumption that individual needs and specifics (political, economic, legal, cultural, historical) of each EU neighbouring country must be taken into account in the course of the ENP. ${ }^{10}$ For example, the ENP embraces two quite diverse groups of the EU' s neighbouring countries. The first group covers countries that signed the EMAAs with the EU that is an association relationship but without any perspective of eventual EU membership. The second group deals with the former Soviet republics that signed the PCAs.

\footnotetext{
${ }^{8}$ For the detailed account of the PCAs and EMAAs see Roman Petrov, Exporting the acquis communautaire through EU External Agreements (NOMOS, Baden-Baden 2011) 313.

${ }^{9}$ For example Communication from the European Commission 'European Neighbourhood Policy Strategy Paper' $\operatorname{COM}(2004) 373$ final at p.3, 8 .

${ }^{10}$ European Commission and High Representative, Joint Communication to the European Parliament, the Council, the European Economic and Social Committee of the Regions, 'A New Response to the Changing Neighbourhood' COM(2011) 303, Brussels, 25 May 2011.
} 
The format of bilateral relations under the framework of the ENP should be marked by some differences and specific features. The ENP proclaims that the 'pace of development of the EU's relationship with each partner country will depend on its degree of commitment to common values, as well as its will and capacity to implement agreed priorities'. ${ }^{11}$ In other words, individual specifics of every neighbouring country and their performance within the ENP action areas are crucial for furthering and deepening their bilateral relations with the EU. ${ }^{12}$ Even within a distinct geographical group of countries the EU does not pursue homogeneous relations with countries of this group. For example the EU's relations with its eastern neighbouring countries take into account pro-European ambitions of Moldova, Ukraine and Georgia and more restrained ambitions in countries like Belarus, Azerbaijan and Armenia. The principle of good neighbourliness complements the principle of differentiation. Indeed the EU neighbouring countries are distinguished by individual domestic security and border situations which must be taken into account by the EU in the course of application of the principle of differentiation. For example Azerbaijan and Armenia have continuing security dispute over the area of NagornoKarabakh, Moldova, Georgia and Ukraine faced challenge of dealing with unrecognised breakaway territories. Therefore the EU's policies towards these countries must be in line with the principles of good neighbourliness and differentiation.

\section{b) Principle of conditionality}

The principle of conditionality finds frequent references in the EU's documents on the ENP. Referring to the 'step - by - step approach' the European Commission stated that 'new benefits should only be offered to reflect the progress made by the partner countries in political and economic reform. In the absence of progress, partners will not be offered these opportunities'. ${ }^{13}$

The principle of conditionality takes its origin from the EU Accession Process. Monitoring mechanism introduced in the ENP resembles the Accession Process applied during the latest waves of the EU enlargement. It envisages not only structural incentives but also a financial and technical assistance. ${ }^{14}$

The application of the principle of conditionality in the context of the Accession Process required candidate countries to pursue various legal and political reforms as to ensure not only the implementation, but also the effective application of the EU acquis, through appropriately functioning national administrative and judicial structures which in many cases imply revision of national constitutional law. ${ }^{15}$ On the whole, the objective of the principle of conditionality is the fulfilment by candidate countries of the Copenhagen and Madrid Criteria in order to qualify for the full EU membership. For this purpose the 'after-Lisbon' version of Article 49 TEU considerably empowers the principle of conditionality. First, the Lisbon Treaty made the EU membership conditional on candidate countries' commitment to 'respect' common European values listed in Article 2 TEU [human dignity, equality and respect for human rights, including

\footnotetext{
${ }^{11}$ Communication from the European Commission 'European Neighbourhood Policy Strategy Paper' COM(2004) 373 final at p. 8 .

${ }^{12}$ Communication from the European Commission 'European Neighbourhood Policy Strategy Paper' COM(2004) 373 final. Joint Communication the European Parliament, the Council, the European Economic and Social Committee and the Committee of Regions 'A New Response to a Changing Neighbourhood' (COM(2011) 303).

${ }^{13} \operatorname{COM}(2003) 104$ final.

${ }^{14}$ Regulation (EU) 232/2014 of 11 March 2014 establishing a European Neighbourhood Instrument (OJ L77/27).

${ }^{15}$ Adam Lazowski, 'And then They were Twenty-Seven ... a Legal Appraisal of the Sixth Accession Treaty' (2007) 44 CML Rev. 401-430, 420.
} 
the rights of persons belonging to minorities]. Second, the Lisbon Treaty requires candidate countries not only to respect these values and also to be committed to 'promote' them. ${ }^{16}$ From practical point of view it could mean that candidate countries should be able to show that they pursue their internal and external policies in line with the EU internal (promotion of market economy, liberalization of markets) and external (promotion of human rights, fight with terrorism and international crime, etc).

However, in contrast to the Accession Process the ENP incentives are of much lesser scale and, therefore, have limited impact on the neighbouring countries. ${ }^{17}$ The ENP and its regional initiatives do not pursue an objective of either the full EU membership or the complete wavering of visa regime and therefore are not so attractive for third countries as the accession process for the countries of the Central and Eastern Europe. Any progress in integration between the EU and the neighbouring countries is conditional upon progress made by the latter within specific action areas. ${ }^{18}$ So vague and ambitious objectives but without sufficient technical and financial assistance on behalf of the EU discouraged the neighbouring countries to pursue effective domestic reforms and, in some cases (for example, in Armenia and Ukraine (in the end of 2013)) caused considerable dissatisfaction of national governments with the principle of conditionality and, eventually, led to abrupt U-turn of their external policies from the EU towards alternative integration projects. ${ }^{19}$ It may be argued that the principle of good neighbourliness as well as any of the EU's common values complement the principle of conditionality since any actions contrary to the spirit of good neighbourliness (causing security or border conflicts) between the EU neighbouring countries would immediately trigger the application of the conditionality on behalf of the EU like it was done with regard to Belarus. ${ }^{20}$

\section{c) Principle of joint ownership and common values}

The principle of joint ownership and common values first appeared in the ENP Strategy Paper in 2004 and means that both the EU and the neighbouring countries have shared participation in shaping and implementing the ENP.

The principle of joint ownership in the ENP is underpinned by the principle of sharing common values. ${ }^{21}$ The ENP provides that relations between the EU and the neighbouring

\footnotetext{
${ }^{16}$ Articles 21(1) TEU.

17 On this issue see Dimitry Kochenov, EU Enlargement and the Failure of Conditionality: Pre-accession Conditionality in the Fields of Democracy and the Rule of Law (Kluwer Law International, 2008) 358 and Dimitry Kochenov, 'Overestimating Conditionality' in Inge Govaere et al. (eds), The European Union in the World: Essays in Honour of Marc Maresceau (Martinus Nijhoff, Leiden 2013) 541-556.

${ }^{18}$ They are: 1) strengthen the rule of law, democracy and respect for human rights; 2) promote market-oriented economic reforms; 3) promote employment and social cohesion; 4) cooperate on key foreign policy objectives such as countering-terrorism and the non-proliferation of weapons of mass destruction).

${ }^{19}$ On this issue see Kataryna Wolczuk, 'Implementation without Coordination: The Impact of EU Conditionality on Ukraine under the European Neighbourhood Policy', 61(2) Europe-Asia Studies 187-211 (2009). Oana Mocanu, 'Brief Overview on the Conditionality in the European Neighbourhood Policy' 10(4) Romanian Journal of European Affairs (2010), available at SSRN <http://ssrn.com/abstract=1727247>, accessed 20.09.2014.

${ }^{20}$ The EU's sanctions against Belarus concerned violations by the latter of the EU's common values - systematic crackdown of opposition and violation of human rights. The EU imposed visa ban and assets freeze on Belarusian President Lukachenko and over 150 key officials (Council Decision 2013/534/CFSP of 29 October 2013 amending Decision 2012/642/CFSP concerning restrictive measures against Belarus (OJ L288/69 2013).

21 'The ENP is an offer made by the EU to its partners to which they have responded with considerable interest and engagement. Joint ownership of the process, based on the awareness of shared values and common interests, is
} 
countries 'will build on mutual commitment to common values ${ }^{22}$ principally within the fields of the rule of law, good governance, the respect for human rights, including minority rights, the promotion of good neighbourly relations ${ }^{23}$, and the principles of market economy and sustainable development'. ${ }^{24}$ The EU's financial and technical support to the neighbouring countries will pursue the objective of promoting good neighbourly relations within the EU's neighbourhood. ${ }^{25}$ Therefore the ENP explicitly recognises the principle of good neighbourliness as part of the EU common values to be shared by the EU neighbouring countries.

In spite of their rhetorical reference to 'shared common values' the ENP pursues the objective of promoting and protecting 'the EU's fundamental values and objectives'. ${ }^{26}$ It also relates to the principle of good neighbourliness. ${ }^{27}$ The EU institutions enjoy a privilege of defining the content and scope of this principle and to supervise the adherence of the neighbouring countries. Therefore the matter of interpretation of the content and scope of the principle of good neighbourliness within the ENP belongs exclusively to the EU institutions.

The principle of joint ownership and common values finds its application in bilateral Action Plans that the EU introduced vis-à-vis each neighbouring country. It is envisaged that designing and actual implementation of the Action Plans should be done jointly by the EU and a concerned neighbouring country. However, there is a lot of criticism towards the actual application of the principle of joint ownership and common values. ${ }^{28}$ For example, bilateral Action Plans are being regularly monitored by the Commission by means of issuing of annual country reports in line with the principles of differentiation, conditionality and joint ownership. ${ }^{29}$ However, in practice, the Commission's annual country reports are not always based on sufficient knowledge about the interests, expectations and needs of the neighbouring countries. ${ }^{30}$

\subsection{Action Plans, Association Agenda and Association Agreements}

essential. The EU does not seek to impose priorities or conditions on its partners'. European Neighbourhood Policy Strategy Paper (COM(2004) 373 final) p. 8.

${ }^{22}$ Emphasis added.

${ }^{23}$ Emphasis added.

24 European Neighbourhood Policy Strategy Paper (COM(2004) 373 final) p. 8.

${ }^{25}$ Article 2(e), Regulation (EU) 232/2014 of 11 March 2014 establishing a European Neighbourhood Instrument (OJ L77/27).

${ }^{26}$ This view is advocated by many scholars and experts. For example, see Kataryna Wolczuk 'Implementation without Coordination: The Impact of EU Conditionality on Ukraine under the European Neighbourhood Policy' (2009) 61(2) Europe-Asia Studies 187-211. Rilka Dragneva, Kataryna Wolczuk EU Law Export to the Eastern Neighbourhood in EU External Relations Law and Policy in the Post-Lisbon Era (P. J. Cardwell ed.) The Hague, T.M.C. Asser Press 2012 218-240.

${ }^{27}$ Article 1, Regulation (EU) 232/2014 of 11 March 2014 establishing a European Neighbourhood Instrument (OJ L77/27).

${ }^{28}$ E.g. Julia Langbein 'European Union Governance towards the Eastern Neigbourhood: Transcending or Redrawing Europe's East-West Divide?' (2014) 52(1) JCMS 157-174. Lieve Van Hoof, 'Why the EU is Failing in its Neighbourhood: The Case of Armenia', (2012) 17(2) EFARev. 285-302.

${ }^{29}$ Communication from the European Commission 'On the Commission Proposals for Action Plans under the European Neighbourhood Policy (ENP)' COM(2004) 795 final.

${ }^{30}$ More on this see Elena Korosteleva 'The European Union and its Eastern Neighbours: Towards a more ambitious partnership?' (Routledge, 2012). Elena Korosteleva (ed) 'Eastern Partnership: A New Opportunity for the Neighbours?' (Routledge, 2011). 
Bilateral Action Plans and Association Agenda (applied only towards Ukraine since November 2009) clarify the precise scope of the EU acquis to be adopted by a neighbouring state. For example, in the case of Ukraine, the eventual aims of the ENP are: 1) the establishment of a free trade area between the EU and Ukraine; 2) access to selected segments of the EU Internal Market and the EU 'financial packages'. 31

In return for progress in abovementioned fields the EU offers to the neighbouring countries greater integration into European programmes and networks, increased technical and financial assistance; enhanced access to the EU Internal Market, improved cross border cooperation with the EU and visa liberalization. Implementation of the Action Plans by the neighbouring countries is closely monitored and regular progress reports are prepared by the European Commission.

The Action Plans do not refer to the principle of good neighbourliness but substitute it with 'cross-border cooperation and shared responsibility in conflict prevention'. ${ }^{32}$ For instance, the EU-Ukraine Action Plan engages Ukraine into solving the Transnistria conflict in Moldova but fails to envisage any common action to solve border issues of Ukraine with Russia. ${ }^{33}$ The principle of good neighbourliness finds its further articulation in the new generation of the EU association agreements (AA) with the eastern neighbouring countries. The EU-Ukraine AA is the first of a new generation of AAs to be concluded between the EU and the Eastern Partnership countries (Ukraine, Moldova, Belarus, Armenia, Azerbaijan and Georgia). ${ }^{34}$ The negotiations on the EU-Ukraine AA were launched in September 2008 and successfully completed in December 2011. The signature of the political part of the EU-Ukraine AA took place on 21 March 2014 in Brussels. ${ }^{35}$ As a whole text the EU-Ukraine AA (including the titles on sectoral cooperation and Deep and Comprehensive Free Trade Area) was signed on 27 June 2014 in Brussles together with the AAs with Moldova and Georgia and ratified by the European Parliament and the Parliament of Ukraine (Verhovna Rada) on 16 September 2014. The AAs essentially aim to deepen the political and economic relations between Ukraine, Moldova and Georgia and the EU through the establishment of an enhanced institutional framework and innovative provisions on regulatory and legislative approximation. Of particular significance of the AAs is the ambition to set up a Deep and Comprehensive Free Trade Areas (DCFTA), leading to gradual and partial integration of Ukraine, Moldova and Georgia in the EU internal market. ${ }^{36}$ Accordingly, the AAs belong to the selected group of 'integration-oriented agreements', i.e. agreements including principles, concepts and provisions which are to be interpreted and applied as if Ukraine,

\footnotetext{
${ }^{31}$ Texts of the Action Plans and Association Agenda are available at <http://eeas.europa.eu/enp/documents/actionplans/index_en.htm>, accessed 19.06.2014.

${ }_{32}^{32}$ For example, see the EU-Ukraine Action Plan.

${ }^{33} \mathrm{Ibid}$, at 2.1 .

${ }^{34}$ EU-Ukraine Association Agreement (OJ L161/2014).

${ }^{35}$ In accordance with Council Decision of 17 March 2014 '(OJ L161/2014) the parties signed only preamble, Article 1 , title 1 (general principles), title 2 (political dialogue and coopration in the field of foreign and security policy) and title 7 (common institutions and final provisions) of the EU-Ukraine Association Agreement. This is only a handful part of the volumnious agreement. See A. Rettman, 'EU and Ukraine sign $2 \%$ of association treaty'<http://euobserver.com/foreign/123574> accessed 22.06.2014.

${ }^{36}$ For more detail see Odysseas Spiliopolus 'The EU-Ukraine Association Agreement as a Framework of Integration between the Two Parties' (2014) 9 Procedia Economics and Finance 256-263. Peter Van Elsuwege, Guillaume Van der Loo, Roman Petrov 'The EU-Ukraine Association Agreement: Assesment of an Innovative Legal Instrument' EUI Working Papers, 2014/09. Available at <http://cadmus.eui.eu/handle/1814/32031>, accessed 20.09.2014.
} 
Moldova and Georgia accede to the EU. The principle of good neighbourliness was given a prominent place among the essential elements of the AAs between the EU and its eastern neighbours. ${ }^{37}$ Furthermore this principle is encapsulated in provisions of the AAs on regional stability wherein it provides that 'the Parties shall intensify their joint efforts to promote stability, security and democratic development in their common neighbourhood, and in particular to work together for the peaceful settlement of regional conflicts'. 38 The regional stability provisions in the AAs between the EU and its eastern neighbours are ad hoc tailored in order to reflect specific countries security issues of concern in line with the principle of differentiation. For example the article on regional stability in the EU-Moldova AA contains the commitment of the Parties 'to a sustainable solution to a Transnistrian issue, in full respect of the sovereignty and territorial integrity of the Republic of Moldova'. ${ }^{39}$ Similar provision in the EU-Georgia AA underlines that the Parties 'shall work towards peaceful settlement of the unresolved conflicts in the region, 40 thereby meaning the frozen conflict between Georgia and Russia over Abkhazia and South Ossetia. However the AAs are nowhere close to providing any firm commitments on the EU to provide any sort of military, financial or technical assistance in case escalating security threats to the parties of the agreements.

\section{The principle of good neighbourliness and security challenges in the countries of the Eastern Partnership}

3.1 The Eastern Partnership as a case for assessing the effectiveness of the principle of good neighbourliness

The Eastern Partnership (EaP) represents a perfect case to assess the effectiveness of the application of the principle of good neighbourliness in practice. This policy was born as a region tailored EU's policy towards the countries of Eastern Europe and Southern Caucasus. Initiated in May 2009 at the Prague Summit, the EaP fosters the necessary conditions to accelerate political association and further economic integration between the EU and Armenia, Azerbaijan, Belarus, Georgia, Moldova and Ukraine. ${ }^{41}$

Since its launch in 2009, the EaP has gone a long way in shaping the agenda of cooperation and answering needs in relations between the EU and its eastern neighbours. ${ }^{42}$ The

\footnotetext{
${ }^{37}$ Article 2 of the EU-Ukraine AA, the EU-Georgia AA and the EU-Moldova AA provide that 'Promotion of respect for the principles of sovereignty and territorial integrity, inviolability of borders and independence, as well as countering the proliferation of weapons of mass destruction, related materials and their means of delivery also constitute essential elements of this Agreement'.

${ }^{38}$ Article 9 of the EU-Ukraine AA, Article 8 of the EU-Georgia AA, Article 8 of the EU-Moldova AA.

${ }^{39}$ Article 8 of the EU-Moldova AA. Text of the AA is available on the web site of the EU External Action Service <http://eeas.europa.eu/moldova/assoagreement/assoagreement-2013_en.htm>, accessed 20.09.2014.

${ }^{40}$ Article 8 of the EU-Georgia AA. Text of the AA is available on the web site of the EU External Action Service <http://eeas.europa.eu/georgia/assoagreement/assoagreement-2013_en.htm>, accessed 20.09.2014.

${ }^{41}$ Communication from the Commission and the European Parliament to the Council 'Eastern Partnership' (COM (2008) 823 final). Joint Declaration of the Prague Eastern Partnership Summit (Prague, 7 May 2009) 8435 (Presse 78).

${ }^{42}$ The EaP envisages stronger political engagement with the EU through: the prospect of a new generation of Association Agreements; integration into the EU economy with deep free trade agreements; easier travel to the EU through gradual visa liberalisation, accompanied by measures to fight illegal immigration; enhanced energy security; increased financial assistance; deeper cooperation on environment and climate issues; increased people-to-people contacts and greater involvement of civil society.
} 
initiative has given rise to new platforms for dialogue at the government and expert level (thematic platforms), as well as in the fields of parliamentary and participatory democracy (Euronest; Civil Society Forum and the Conference of the Regional and Local Authorities).

The EaP enhances the scope of the 'shared values' concept by engaging the neighbouring countries to 'the commitment to common values'. ${ }^{43}$ For this purpose the Action Plans and Association Agenda contain specific priorities intended to strengthen the commitment to shared values and to adoption of the EU dynamic acquis. The pace of the eastern neighbouring countries reforms aimed at adoption of the EU acquis is being regularly monitored by the European Commission.

Unfortunately the initial format of the EaP did not take into account several factors that eventually led to serious failures of the entire policy. First, the EaP completely ignored the so called 'Russian factor'. It means the EaP failed to engage the Russian Federation (as an observer) at least into some of its action platforms. Consequently from the very beginning the Russian Federation displayed a great degree of alienation towards the EaP. It simply considered the EaP as a geopolitical project aimed at limiting the Russian area of influence over post-Soviet republics. ${ }^{44}$ Consequently the Russian Federation expressed its lack of trust towards the EaP with regard to the EU-Ukraine Association Agreement. On numerous occasions the Russian Federation emphasised that it was necessary and justice to be involved into negotiations on the AAs (especially with regard to the EU-Ukraine AA) and proposed numerious amendments to the association agreement with Ukraine just on eve of its ratification by both parties. ${ }^{45}$ As a result of Russian pressure doubled with open military support of militant separatists groups in the East of Ukraine the EU and Ukraine had to share negotiation table with representatives of the Russian government. This process led to unprecedented compromise. The EU and Ukraine agreed to postpone the establishment of the DCFTA between them for a year till January 2016. Instead the Russian Federation agreed to maintain free trade relations with Ukraine for the same duration. ${ }^{46}$ It was one of the first occasions in history of EU external relations when a third party intervened into the process of implementation of already signed EU external agreement.

Second, the EaP documents pay very little attention to the external application of the principle of good neighbourliness beyond the borders of the EU's eastern neighbouring countries. Instead the EaP focuses on 'better governance of its Eastern borders' like the Transnistria border between Moldova and Ukraine and does not envisage any assistance to Georgia and Armenia in solving their border and security conflicts with Russia and Azerbaijan respectively. ${ }^{47}$ These

\footnotetext{
${ }^{43}$ For instance, the ENP Strategy Paper provides: 'The privileged relationship with neighbours will build on mutual commitment to common values principally within the fields of the rule of law, good governance, the respect for human rights, including minority rights, the promotion of good neighbourly relations, and the principles of market economy and sustainable development.' (Communication from the European Commission 'European Neighbourhood Policy Strategy Paper' COM(2004) 373 final)

${ }^{44}$ Sergey Lavrov, 'State of the Union Russia-EU: Prospects for Partnership in the Changing World' (2013) 51 JCMS 6-12.

45 Delphine d'Amora 'Russia Wants Say in EU-Ukraine Association', available at http://www.themoscowtimes.com/business/article/russia-wants-to-amend-eu-ukraine-association-deal/506064.html, accessed 20.09.2014.

${ }^{46}$ Joint Ministerial Statement on the Implementation of the EU-Ukraine AA/DCFTA, Brussels, 12 September 2014 , available at http://europa.eu/rapid/press-release_STATEMENT-14-276 en.htm, accessed 20.09.2014.

${ }^{47}$ For instance if the ENP Strategy Paper encourages the participation of the Russian Federation 'as a partner in regional cooperation' (Communication from the European Commission 'European Neighbourhood Policy Strategy Paper' COM(2004) 373 final) the Commission's Communication of the EaP explicitly states that 'The European Union has a vital interest in seeing stability, better governance and economic development at its Eastern borders'
} 
shortages of the EaP seriously undermined any chances of effective application of the principle of good neighbourliness within and beyond the EU's eastern neighbourhood.

3.2 Security challenges within the countries of the Eastern Partnership and the principle of good neighbourliness

It must be admitted that since the launch of the EaP the principle of good neighbourliness has not contributed to better stability and security in the region. On the opposite, the overall security situation in the EU's neighbouring countries has gradually deteriorated. Currently almost all countries of the EaP have unresolved border security conflicts either with other EU's neighbouring countries or with third countries (mainly with the Russian Federation). ${ }^{48}$ A key EaP country Ukraine has been plunged into flames of bloody civil conflict since April 2014.

Moldova experiences prolonged conflict with its breakaway part Transnistria (so called Pridenstrovian Moldovan Republic). This territory is not recognised by any of the UN members and formally constitutes part of the Republic of Moldova (Transnistria autonomous territorial unit with special legal status). However, de facto, Transnistria is an independent state with strong presence of Russian military troops. ${ }^{49}$ The EU is engaged in solving the Transnistrian conflict via the European Border Assistance Mission to Moldova and Ukraine (EUBAM). This structure as part of the EU Common Security and Defence Policy helps to control traffic on borders between Moldova and Ukraine around Transnistria in order to prevent illegal movements of people and goods from and to Transnistria. ${ }^{50}$

Armenia and Azerbaijan are in dispute over status of the self proclaimed and not recognised Nagorno-Karabakh Republic. Conflict over this territory led to large scale war between Armenia and Azerbaijan that ended in ceasefire in 1994.

Georgia went through a military conflict with Russia over the breakaway areas of Abkhasia and South Ossetia. The conflict took place August 2008 and led to many casualties and loss of control of Georgia over Abkhasia and South Ossetia. ${ }^{51}$ Currently Russian military troops are stationed in Abkhasia and South Ossetia and de facto control their territories.

The EU played quite modest role in settling the conflict in the Caucasus allowing some EU Member States to lead the peace process in the region. ${ }^{52}$ No sanctions were applied by the EU in the aftermath of the Georgian-Russian conflict.

Communication from the Commission and the European Parliament to the Council 'Eastern Partnership' (COM (2008) 823 final) and omits any references to Russia in this context.

${ }^{48}$ They are: dispute between Armenia and Azerbaijan over status of the self proclaimed and not recognised Nagorno-Karabakh Republic; military conflict between Georgia and Russia over the breakaway areas of Abkhasia and South Ossetia; conflict between Moldova and with its breakaway part Transnistria; annexation of Crimea by Russia.

${ }^{49}$ Russian 14th Army has been present in the region of Transnistria since the start of the conflict. For more information see < http://en.wikipedia.org/wiki/Transnistria $>$, accessed 20.09.2014.

${ }^{50}$ Xymena Kurowska and Benjamin Tallis, 'Border Assistance Mission: Beyond Border Monitoring?' (2009) 14(1) EFARev. 47-64.

${ }^{51}$ For more detail see Independent International Fact-Finding Mission on the Conflict in Georgia, available at <http://www.ceiig.ch>, accessed 30 May 2014.

${ }^{52}$ SyuzannaVasilyan, 'The External Legitimacy of the EU in the South Caucasus' (2011) 16(3) EFARev. $341-357$. Richard G. Whitman, and Stefan Wolff, 'The EU as a conflict manager? The case of Georgia and its implications' (2010) 86(1) International Affairs 87-107. George Christou, 'Multilateralism, Conflict Prevention, and the Eastern Partnership' (2011) 16(3) EFARev. 207-225. 
However the next security challenge within the EaP compelled the EU to act and to apply sanctions against one of the leading geopolitical players on the European continent - the Russian Federation. It happened after self proclaimed authorities the Autonomous Republic of Crimea hold unrecognised referendum under Russian military presence in March 2014. As a result of this the integral part of Ukraine - the Autonomous Republic of Crimea and the city of Sevastopol - were annexed by the Russian Federation and incorporated by the Russian Federation as own federal subjects on March 21, 2014. The fact of annexation is not recognised by Ukraine and the United Nations ${ }^{53}$ and is universally considered as blatant violation of international public law by the Russian Federation. ${ }^{54}$

Following turbulent events in Crimea the EU decided to apply wide scale sanctions against Russia. The EU sanctions led to a complete halt in the EU-Russia relations (suspension of bilateral talks on visa matters and on new EU-Russia agreement, cancellation of the EURussia summit) and to imposing measures against 'certain persons responsible for actions which undermine or threaten the territorial integrity, sovereignty and independence of Ukraine' (travel bans and asset freezes). ${ }^{55}$ The list of these persons is constantly increasing and covers leading Ukrainian, Russian and Crimean politicians related to the fact of the Crimea's annexation. The EU had to extend the scope of sanctions against Russia after the security situation in Ukraine has drastically deteriorated by the end of the summer 2014. The world was shocked when Malaysia Airline flight MH17 was shot down above the part of Eastern Ukraine controlled by pro-Russian separatists. This incident caused the loss of 298 lives and drastically deteriorated security situation in the region and in the EU. Bloodshed conflict between Ukraine and armies of self proclaimed 'peoples republics' of Donetsk and Lugansk led to several thousand casualties and about a million refugees from the East of Ukraine. ${ }^{56}$ The EU Member States had to speak with one voice in order to show their solidarity against direct Russian involvement into civil conflict in Ukraine. As a result the EU Member States agreed on new level of sanctions against Russian and Ukrainian officials and nationals involved in supporting the separatists' movement in the Donbass region of Ukraine. Hitherto, the EU's sanctions against Russia concerned the following

\footnotetext{
${ }^{53}$ UN General Assembly Resolution 68/262 adopted on 27 March 2014 'Territorial Integrity of Ukraine'. In the meantime only six countries (Afganistan, Cuba, Nicaragua, Russia, Syria and Venezuela ) recognized the Republic of Crimea and Sevastopol as federal subjects of the Russian Federation.

${ }^{54}$ For legal assessment of the annexation of Crimea by the Russian Federation see: Antonello Tancredi, 'The Russian annexation of the Crimea: questions relating to the use of force' and Enrico Milano, 'The non-recognition of Russia's annexation of Crimea: three different legal approaches and one unanswered question', Questions of International Law on 11 May 2014, available at <http://www.qil-qdi.org> accessed 20.09.2014.

${ }^{55}$ Council Regulation (EU) No 269/2014 of 17 March 2014 concerning restrictive measures in respect of actions undermining or threatening the territorial integrity, sovereignty and independence of Ukraine (OJ L78) amended by Council Regulation (EU) No 476/2014 of 12 May 2014 (OJ L137), Council Regulation (EU) No 783/2014 of 18 July 2014 (OJ L214/2), Council Regulations (EU) No 810/2014 and No 811/2014 of 25 July 2014 (OJ L221), Council Regulation (EU) No 959/2014 of 08 September 2014 (OJ L271), Council Implementing Regulation (EU) No 961/2014 of 12 May 2014 (OJ L271/8). Council Decision 2014/145/CFSP concerning restrictive measures in respect of actions undermining or threatening the territorial integrity, sovereignty and independence of Ukraine (OJ L78) amended by Council Decision 2014/265/CFSP of 12 May 2014 (OJ L137). Council Decision 2014/119/CFSP concerning restrictive measures directed against certain persons, entities and bodies in view of the situation in Ukraine (OJ L66). Council Regulation (EU) No 883/2014 of 31 July 2014 concerning restrictive measures in view of Russia's actions destabilising the situation in Ukraine (OJ L229), amended by Council Regulation (EU) No 960/2014 of 08 September 2014 (OJ L271/2).

${ }^{56}$ UN Report on the human rights situation in Ukraine of 17 August 2014, available at http://www.ohchr.org/Documents/Countries/UA/UkraineReport28August2014.pdf> accessed 20.09.2014.
} 
issues: diplomatic measures (cancellation of the EU-Russia political dialogue and dismantling of G8); restrictive measures (asset freezes and visa bans of persons and entities responsible for actions against Ukraine's territorial integrity); restrictions for Crimea and Sevastopol; "economic" sanctions against Russia (prohibition of exports of arms, energy and military related technologies and dual use goods, freezing economic cooperation).

It is too early to judge the effectiveness of the EU sanctions at the time of writing of this paper. On the one hand, the mere fact of issue of the EU sanctions provides a promising picture of the EU solidarity against violations of international law within the EU neighbourhood. The threat of wide scale retaliatory measures on behalf of the Russian Federation against the EU did not prevent the issue of "economic" sanctions against it. On the other hand, the EU can not afford immediate large scale sanctions against its third trading partner - Russia due to its reverse effect on the EU's economy, especially in the field of energy.

The EU sanctions were issued upon unanimous decision of all the EU Member States on basis of Article 215 TFEU as part of the CFSP. This fact represents evident solidarity of all EU Member States facing a violation of territorial integrity of one of its nearest neighbours which is about to enter into association relations with the EU. Nevertheless neither of the EU acts on sanctions against the Russian Federation refers to the principle of good neighbourliness. It shows that the EU does not consider that violation of the principle of good neighbourliness as a legitimate basis of sanctions is not inclined to extend the application of this principle beyond the territory of its neighbouring countries.

\section{Concluding remarks}

Having outlined the nature and scope of application of the principle of good neighbourliness within the ENP we can turn to the concluding remarks.

The ENP was devised as a framework policy of the EU towards its immediate neighbours based on core principles of differentiation, conditionality, joint ownership and adherence to common values. Formally the principle of good neighbourliness complements the ENP's core principles and thereby occupies important place under the framework of the ENP and the EU's regional policies. In practice many of the ENP's objectives including the effective application of the principle of good neighbourliness have not been successfully achieved. For instance the ENP has not prevented escalation of old and new border and security conflicts within and beyond the EU's neighbourhood (Georgia-Russia war, annexation of Crimea). One of the reasons of this is the fact that the ENP contains declarative means and, unfortunately, does not offer practical tools for better application of the principle of good neighbourliness in the EU's neighbourhood. For instance the ENP failed to engage the parties into effective sharing of the principle of good neighbourliness especially in relation to the Caucasus region. Instead most of the ENP's human and financial resources have been invested into ensuring security control over the EU's Eastern and Southern borders. It would seem logical therefore to encourage better engagement of the neighbouring countries into truly joint building and implementation of the principle of good neighbourliness within the EU and beyond. One of the solutions is to extend the scope of application of the principle of good neighbourliness beyond the EU's neighbourhood in cooperation with key security players in the region. The new generation of the AAs between the EU and the eastern neighbouring countries places the principle of good neighbourliness among essential elements of the agreements. Therefore it gives some hopes that the new regulatory framework offered by the AAs will improve the status quo and contribute to safe and good neighbourly 'ring of friends' around the EU borders and beyond. 